\title{
Visoko obrazovanje i razvod braka u međunarodnoj usporedbi: kako nacionalne demografske značajke oblikuju vezu na mikrorazini?
}

DOI: https://doi.org/10.11567/met.34.2.2

UDK: 316.363.5:378]:314.14[(4:497.5)

Izvorni znanstvenih rad

Primljeno: 06.12.2018.

Prihvaćeno: 22.12.2018.

\section{Petra Međimurec}

Katedra za demografiju, Ekonomski fakultet, Sveučilište u Zagrebu, Zagreb pmedimurec@efzg.hr

\section{SAŽETAK}

Ovaj rad istražuje vezu između visokog obrazovanja i razvoda u međunarodnoj perspektivi. Kakva je ta veza u Europi? Varira li među zemljama? Ovisi li i kako o nacionalnim demografskim značajkama? Kakva je Hrvatska u usporedbi s drugim europskim zemljama? Kako bi se ponudili odgovori na postavljena pitanja, u radu se procjenjuju višerazinski regresijski modeli, na temelju podataka iz pete runde Europskoga društvenog istraživanja. Analiza obuhvaća muškarce i žene iz 25 zemalja. Rezultati pokazuju da visoko obrazovanje spušta šanse za razvod među Europljanima i Europljankama. No europske se zemlje jedna od druge bitno razlikuju. U zemljama poput Hrvatske, gdje su promjene u obiteljskom ponašanju koje prate drugu demografsku tranziciju još uvijek relativno slabe, veza između visokog obrazovanja i razvoda ima manje negativan (više pozitivan) predznak. S druge strane, u zemljama gdje su manje tradicionalni obiteljski oblici česti, među visokoobrazovanim muškarcima i ženama manja je vjerojatnost za razvod. To je u skladu s teorijskim pretpostavkama i dosadašnjim empirijskim nalazima, a može imati važne implikacije za socioekonomsku nejednakost u modernim društvima.

KLJUČNE RIJEČI: razvod, obrazovanje, međunarodna usporedba, Europa, višerazinska analiza

\section{UVOD}

Danas se u Europi razvodi više brakova nego sredinom prošlog stoljeća (Eurostat, 2018a). No razvod je bez obzira na taj opći porast češći ne samo u nekim zemljama nego i u nekim društvenim kategorijama (Härkönen i Dronkers, 2006: 501). Socioekonomske razlike u šansama za razvod privlače posebnu istraživačku pozornost jer razvod može imati negativne posljedice 
za odrasle i djecu (Amato, 2000, 2014), a ako se pretežno razvode oni koji se već ionako nalaze u relativno nepovoljnijem položaju, onda to prema argumentima iz postojeće literature (McLanahan, 2004; McLanahan i Percheski, 2008; McLanahan i Jacobsen, 2015; Härkönen, 2017) može proširiti društvenu nejednakost i pogoršati životne šanse za djecu iz razvedenih obitelji.

Kad se u empirijskim istraživanjima povezuje sa šansama za razvod, socioekonomski status često se aproksimira obrazovanjem, zato što obrazovanje dobro odražava raspoložive financijske i društvene resurse (Härkönen i Dronkers, 2006; Kalmijn, 2013; Dronkers, 2015). Nalazi iz takvih istraživanja pokazuju da obrazovni gradijent $u$ razvodu nema isti predznak u svim zemljama i da smjer koji poprima može ovisiti o kontekstualnim uvjetima.

Ovaj rad istražuje vezu između visokog obrazovanja i razvoda u 25 europskih zemalja. Cilj je višestran: a) procijeniti tu vezu na mikrorazini, b) ispitati varira li među europskim zemljama i c) utvrditi ovisi li i kako o nacionalnim demografskim značajkama.

U nastavku se najprije ukratko iznosi teorijska podloga, a uvodno poglavlje na tom temelju završava istraživačkim pitanjima i hipotezama. Zatim slijedi dio o podacima i metodama. U radu se kombiniraju mikro- (anketni) i makropodaci i sve zemlje analiziraju se u jednom koraku, višerazinskim modelima. Treće poglavlje prikazuje proizašle rezultate, uz interpretacije s naglaskom na hrvatskom primjeru u europskom okruženju, a u zadnjem poglavlju raspravlja se o ograničenjima provedenog istraživanja i donose se zaključci sa smjernicama za buduća istraživanja.

\subsection{Teorijska podloga: veza između obrazovanja i razvoda u međunarodnoj perspektivi}

Kako je obrazovanje povezano sa šansama za razvod? Različite teorijske perspektive na isto pitanje nude različite odgovore. Pojedine perspektive na primjer sugeriraju da visokoobrazovani bračni partneri imaju liberalnije stavove, zbog kojih spremnije prihvaćaju manje tradicionalno obiteljsko ponašanje kao što je razvod (Levinger, 1976; Salvini i Vignoli, 2011). Doduše, većina se ekonomskih i psihosocijalnih teorija ipak slaže u pretpostavci da visoko obrazovanje kao socioekonomski resurs spušta šanse za razvod među muškarcima (Jalovaara, 2003). Za žene je, s druge strane, priča malo kompliciranija. Beckerov model (Becker, 1974, 1993; Becker, Landes i Michael, 1977) sugerira da su šanse za razvod (naj)manje kad među bračnim partnerima postoji specijalizacija u obiteljskim ulogama. Muškarcima pritom tipično pripada uloga hranitelja obitelji, dok su žene zadužene za brigu o djeci i kućanstvu. Zato su među visokoobrazovanim muškarcima šanse 
za razvod niže: oni imaju veći potencijal za bolju zaradu i obično ostvaruju bolji imovinski status, pa mogu lakše uzdržavati obitelj. Ženama međutim visoko obrazovanje nudi ekonomsku samostalnost i otvara prilike na tržištu rada, što podiže šanse za razvod jer smanjuje prednosti od tradicionalne muško-ženske podjele poslova u obitelji. Suprotno, Beckerovi kritičari (Oppenheimer, 1997) i za žene predviđaju negativnu vezu između visokog obrazovanja i razvoda, ističući da je specijalizacija u obiteljskim ulogama među bračnim partnerima rizična i nefleksibilna strategija $u$ suvremenim društveno-gospodarskim uvjetima. Dodatno, neki autori visoko obrazovanje povezuju s boljim kognitivnim, društvenim i komunikacijskim vještinama koje smanjuju šanse za razvod jer bračnim partnerima pomažu da uspješnije riješe eventualne razmirice (Amato, 1996; Blossfeld, 2014).

I empirijski su nalazi mješoviti i pokazuju da je veza između obrazovanja i razvoda u nekim zemljama i u nekim bračnim kohortama pozitivna, a u drugim zemljama i pretežno u mlađim bračnim kohortama negativna (Härkönen i Dronkers, 2006; Matysiak, Styrc i Vignoli, 2014; Dronkers, 2015). Poznate sociološke i demografske teorije objašnjavaju moguće razloge.

William Goode vjerojatno je prvi vezu između obrazovanja (tj. socioekonomskog statusa ${ }^{1}$ i razvoda povezao s društvenim kontekstom. U svojoj je teoriji (Goode, 1962, 1993) predvidio da modernizacija tu vezu iz pozitivne mijenja u negativnu. Pozitivna veza može se očekivati u zemljama gdje se razvod (još uvijek) događa rijetko, pa traži dodatne socioekonomske resurse (tj. visoko obrazovanje). No u zemljama gdje su društvene i ekonomske zapreke razvodu niske javlja se negativna veza, odnosno češće se razvode niži društveni slojevi, čiji lošiji socioekonomski status, objašnjava Goode (1951, 1962), u pravilu narušava kvalitetu obiteljskog života i tako podiže šanse za razvod.

I druge teorijske perspektive pozivaju se na argumente koji navode na slične zaključke. Prema teoriji o drugoj demografskoj tranziciji (van de Kaa, 1987; Lesthaeghe, 1995) na primjer, novo i manje tradicionalno obiteljsko ponašanje najprije usvajaju oni visokoobrazovani, koji lakše krše prevladavajuće društvene norme jer raspolažu potrebnim socioekonomskim resursima (Lesthaeghe i Surkyn, 1988). S tim u skladu Blossfeld i sur. (1995) objašnjavaju da se u zemljama gdje se brakovi razvode po niskim stopama može očekivati pozitivna veza s obrazovanjem, zato što je razvod »teže« odstupanje od normativnih očekivanja. Takva veza slabi i može prijeći u negativnu (Hoem, 1997) u zemljama gdje je razvod češći, odnosno u zemljama

Goode se i sam u svojim radovima koristio obrazovanjem kao mjerom socioekonomskog statusa (Goode, 1962: 522). 
gdje su stavovi o braku i obitelji liberalniji, pa su, Goodeovim rječnikom, i zapreke razvodu niže.

\subsection{Istraživačka pitanja}

Ovaj rad postavlja tri istraživačka pitanja. Prvo glasi: $U$ kakvoj su vezi šanse za razvod i visoko obrazovanje u Europi? Odgovor će pokazati koji od ponuđenih teorijskih mehanizama općenito dominira među Europljanima i Europljankama. No Europa je heterogena i kontekst u kojem se odvija obiteljski život razlikuje se od zemlje do zemlje, pa je teško pretpostaviti da je veza između visokog obrazovanja i razvoda posvud ista. Zato je drugo istraživačko pitanje: Varira li ta veza među zemljama? Moglo bi biti da će odgovor ovisiti o spolu jer dosadašnja istraživanja, u skladu s teorijskim pretpostavkama, dokumentiraju puno postojaniju i uglavnom negativnu vezu za muškarce (Salvini i Vignoli, 2011: 149). Također u skladu s teorijskim pretpostavkama, može se očekivati da je veza između obrazovanja i razvoda manje pozitivna odnosno više negativna u zemljama gdje su promjene koje donosi druga demografska tranzicija (Lesthaeghe, 1995) raširenije, zato što su zapreke razvodu u tim zemljama manje. Dakle treće je istraživačko pitanje: Ovisi li i kako veza između visokog obrazovanja i razvoda o nacionalnim demografskim značajkama i kakva je Hrvatska u usporedbi s drugim europskim zemljama? Odgovor će otkriti jesu li kontekstualne varijable sustavno povezane s obrazovnim gradijentom $u$ razvodu među muškarcima i ženama u Europi i kakva je u tom pogledu Hrvatska u odnosu na ostale zemlje u analizi.

\section{PODACI I METODE}

Ovaj rad koristi se Europskim društvenim istraživanjem (European Social Survey), podacima iz pete runde (ESS, 2010), u kojoj je sudjelovala i Hrvatska. Primjenjujući visoke metodološke standarde, Europsko društveno istraživanje prikuplja usporedive međunarodne podatke, koji su u integriranoj bazi javno dostupni. ${ }^{2}$ Europsko društveno istraživanje zasniva se na intervjuima licem u lice s ispitanicima iz slučajnog uzorka u svakoj uključenoj zemlji. Iako su podaci presječni, prikladni su za potrebe ovog rada jer omogućuju da se obrazovne razlike u šansama za razvod istraže iz mikromakro perspektive.

Integrirana baza za petu rundu ne sadržava podatke za Austriju, koja je u odnosu na ostale zemlje kasnije provela anketu. 
Uzorak za ovu analizu ograničen je na muškarce i žene koji su u petoj rundi imali najmanje 35 godina i najviše 54 godine. Dobni raspon postavljen je tako da, s jedne strane, pokriva ljude koji su uglavnom završili školovanje i da, s druge strane, eliminira moguće učinke selektivnog mortaliteta prema obrazovanju i bračnom stanju. Uzorak isključuje sve muškarce i žene koji nisu (bili) u braku jer oni nikad nisu ni bili izloženi riziku od razvoda. Uzorkom su obuhvaćeni podaci za 25 europskih zemalja. U podacima za Finsku postoji pogreška u varijabli o bračnom stanju, a Izrael ne ulazi u uzorak jer je fokus na europskim zemljama. Iz uzorka su također uklonjena opažanja s nedostajućim vrijednostima u zavisnoj varijabli ili (mikro) prediktorima (približno 1,6\%). To je uzorak svelo na 5579 muškaraca (u prosjeku 223,2 po zemlji) i 7338 žena (u prosjeku 293,5 po zemlji).

Razvod je zavisna varijabla u analizi. Kodirana je kao 0 ako muškarac ili žena u uzorku nisu nikad bili razvedeni, odnosno kao 1 ako su se nekad razveli. ${ }^{3}$ Razvedenih muškaraca u uzorku ima približno $21,9 \%$, a razvedenih žena približno $26,0 \%$.

\subsection{Mikro- i makroprediktori}

Visoko obrazovanje ključna je nezavisna varijabla na mikrorazini. Europsko društveno istraživanje harmonizira podatke o obrazovanju tako da budu usporedivi među svim uključenim zemljama. U ovu analizu visoko obrazovanje ulazi kao indikator-varijabla, a kodirana je kao 0 ako muškarac ili žena u uzorku nemaju visoko obrazovanje, odnosno kao 1 ako su muškarac ili žena u uzorku završili visoko obrazovanje. Visoko obrazovanje pritom pokriva samo tercijarno obrazovanje (ISCED 2011 razine 6 i naviše, tj. najmanje prvostupnički ili ekvivalentan akademski stupanj).

U analizu ulaze i sljedeće kontrolne (mikro) varijable: dob, migrantska obilježja i religioznost. Dob je kodirana kao kategorijska varijabla, uz kategorije $35-39,40-44,45-49$ i $50-54$. Varijabla o migrantskim obilježjima pokazuje jesu li muškarci i žene u uzorku rođeni u zemlji u kojoj su intervjuirani. Kodirana je kao 0 ako jesu, odnosno kao 1 ako nisu. Varijabla koja mjeri religioznost izvedena je iz anketnog pitanja o prisutnosti na

\footnotetext{
Ispitanike se pitalo jesu li ikad bili razvedeni ili razvrgnuli zakonski priznatu izvanbračnu zajednicu, no te se dvije kategorije iz ponuđenih odgovora (da ili ne) ne mogu međusobno razlikovati. U Hrvatskoj zakonski priznatu izvanbračnu zajednicu čini zajednica između muškarca i žene s trajanjem od najmanje tri godine (ili s kraćim trajanjem ako partneri imaju dijete). Za definicije u ostalim zemljama vidjeti napomene iz dokumentacije uz petu rundu (ESS, 2018). Dakle analiza u ovom radu tretira razvod i prekid zakonski priznate izvanbračne zajednice kao iste događaje. Dodatno, ovo se pitanje u petoj rundi promijenilo u odnosu na prethodne runde (i nije sasvim usporedivo). Budući da je peta runda posljednja u kojoj je sudjelovala i Hrvatska, ovaj rad koristi se tim podacima.
} 
religijskim obredima (izuzimajući posebne događaje kao što su vjenčanja i sprovodi). Postavljena je kao indikator-varijabla s vrijednostima 0 (za ispitanike koji prisustvuju religijskim obredima rjeđe od jednom tjedno) i 1 (za ispitanike koji prisustvuju religijskim obredima najmanje jednom tjedno).

Kako bi se obrazovni gradijent $u$ razvodu povezao s nacionalnim demografskim značajkama, analiza obuhvaća i varijablu na makrorazini, koja spaja tri agregirana pokazatelja. To su za svaku zemlju u uzorku: postotni udio ikad razvedenih, postotni udio onih koji su ikad kohabitirali (tj. živjeli s partnerom, a da nisu bili u braku) i postotni udio živorođenih izvan braka. Prva su dva pokazatelja dobivena iz pete runde Europskoga društvenog istraživanja, na temelju čitavog uzorka (a ne samo za dobni raspon koji ulazi u ovu analizu). ${ }^{4}$ Treći je preuzet s Eurostata (2018b). Tri pokazatelja zajedno čine dobru skalu na makrorazini (uz Cronbachov alfa koeficijent > 0,80 ) i ova analiza spaja ih u jednu (makro) varijablu, tzv. DDT indeks (tj. indeks koji za svaku zemlju u uzorku raširenost druge demografske tranzicije mjeri prosjekom triju pokazatelja). Kako bi se olakšala interpretacija, varijabla DDT indeks centrirana je oko svojeg minimuma, odnosno oko vrijednosti koja je dobivena za Hrvatsku.

\subsection{Modeli}

U radu je provedena višerazinska analiza (npr. Snijders i Bosker, 1999), u kojoj su dvije razine muškarci odnosno žene (mikro) i europske zemlje (makro). Ključna je prednost višerazinske analize to što uvažava da bi opažanja koja se odnose na muškarce i žene u istoj zemlji mogla biti međusobno zavisna. Uzimajući to u obzir, višerazinska analiza dopušta da se u jedan statistički model istovremeno uključe i mikro- i makroprediktori i da se ispitaju njihove interakcije.

Posebno za muškarce, posebno za žene, procijenjeni su (dvorazinski) modeli binarne logističke regresije (zavisna je varijabla binarna). Pratila se uobičajena praksa i modeli su izgrađeni postupno: krenulo se s najjednostavnijom specifikacijom, koja se u sljedećim koracima proširivala. Pritom se u svakom koraku LR testom (tj. likelihood-ratio testom) ispitivalo je li složenija specifikacija statistički bolja od jednostavnije.

Najprije su za muškarce i žene procijenjeni prazni, nulti modeli (oni koji ne sadržavaju ni mikro- ni makroprediktore). Ti modeli potvrdili su da šan-

$4 \quad$ Kako bi proizašli postotni udjeli bili usporedivi među zemljama, distribucije su, u skladu s preporukama (ESS, 2014), vagane ponderima koji korigiraju za nejednaku vjerojatnost odabira u uzorak (tzv. design weights). Podatak o udjelu onih koji su ikad kohabitirali nedostaje za Irsku. 
se za razvod variraju među europskim zemljama, što opravdava primjenu višerazinske analize. Pokazalo se da na razlike među zemljama otpada 7,0\% ukupne varijance u šansama za razvod kod muškaraca i 7,3\% varijance u šansama za razvod kod žena.

U modelu 1 nultoj je specifikaciji dodana samo varijabla o obrazovanju, a u modelu 2 uključene su i kontrolne varijable na mikrorazini. Ti modeli odgovaraju na prvo istraživačko pitanje, odnosno pokazuju u kakvoj su vezi visoko obrazovanje i šanse za razvod među Europljanima i Europljankama.

U sljedećem koraku ispitano je varira li obrazovni gradijent u razvodu među europskim zemljama, pa je u model 3 uvršten slučajan koeficijent za varijablu o obrazovanju. Model 3 dakle ima za cilj odgovoriti na drugo istraživačko pitanje.

Zatim se u model 4 uvrstio i DDT indeks, tj. varijabla na makrorazini, a procjene otkrivaju koliko varijance u šansama za razvod među europskim zemljama objašnjavaju razlike u nacionalnim demografskim značajkama. U modelu 5 procijenjena je interakcija između (mikro) visokog obrazovanja i (makro) DDT indeksa. Taj model odgovara na posljednje istraživačko pitanje jer proizašla mikro-makro interakcija pokazuje kako obrazovni gradijent u razvodu ovisi o raširenosti druge demografske tranzicije u nekoj zemlji.

Svi izračuni odrađeni su uz softversku podršku STATA 14.2, ${ }^{5}$ a tekstni dokument s kodom i svim pripadajućim rezultatima dostupan je od autorice na zahtjev.

\section{REZULTATI}

Rezultati se u nastavku iznose u dva dijela. Prvo se prikazuje deskriptivna statistika za sve varijable i zemlje u uzorku, a zatim procjene iz dvorazinske logističke regresije.

\subsection{Deskriptivna statistika}

Tablica 1 detaljno opisuje uzorak u višerazinskoj analizi. Najprije je za svaku zemlju naveden DDT indeks, a vrijednosti u narednim stupcima odnose se na varijable na mikrorazini.

StataCorp (2015.), Stata Statistical Software: Release 14. College Station, TX: StataCorp LP. 


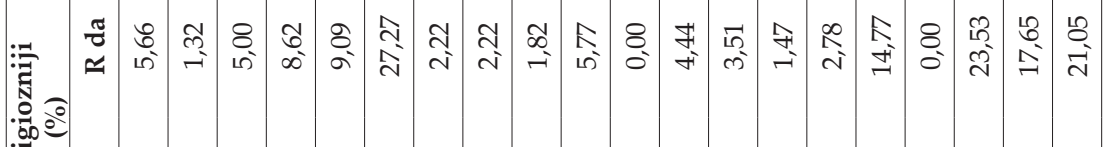

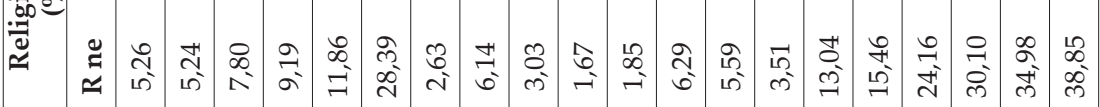

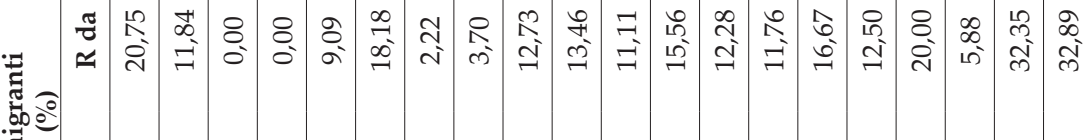
票

$\frac{\pi}{\frac{\pi}{\pi}}$

응 :

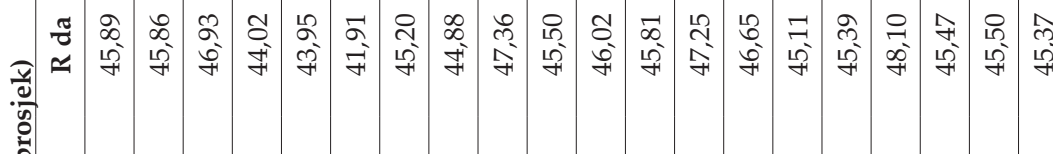

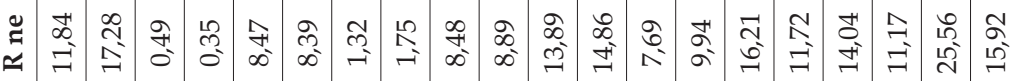

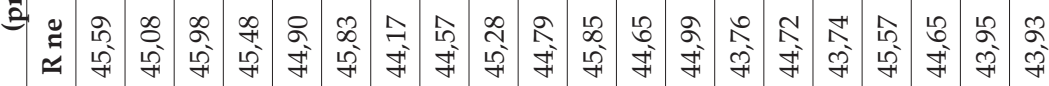

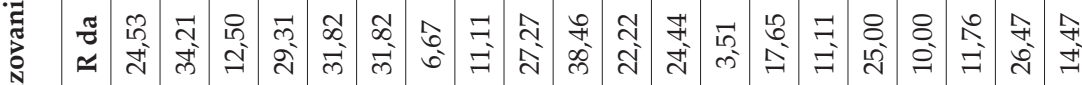
ํํㅇ

䓪

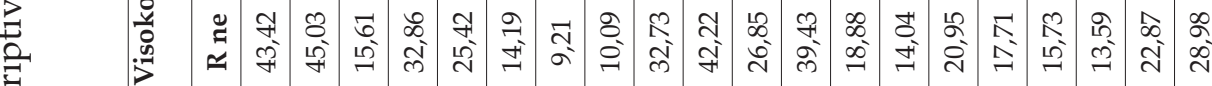

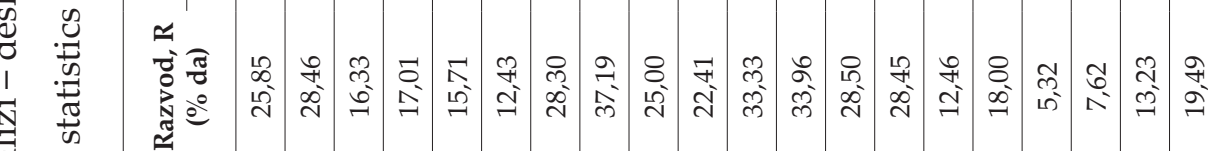

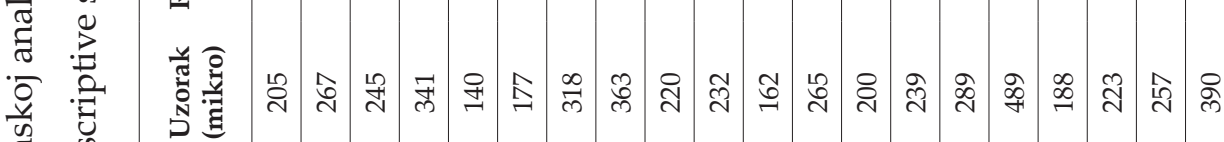

근

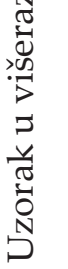

-

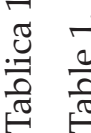

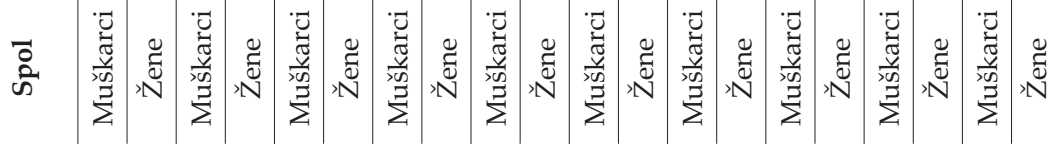

穴

ते तี

年

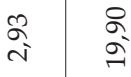

갈

$\infty$
$\stackrel{\infty}{\infty}$
$\stackrel{n}{\infty}$

옹

$\begin{array}{lll}\pi & 8 & 0 \\ 0 & 0 & 0 \\ 0\end{array}$

ํㅠㅁ

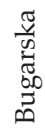

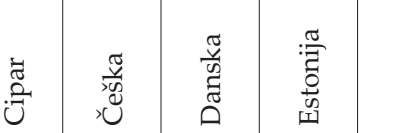

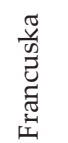

焉 苞




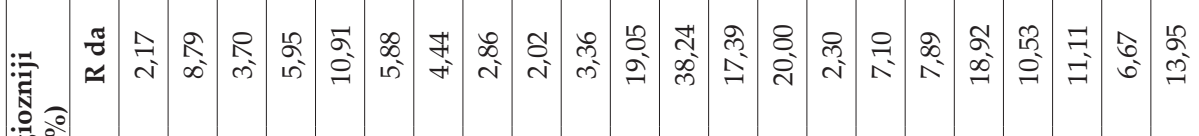
$\because \frac{0}{0} \div$

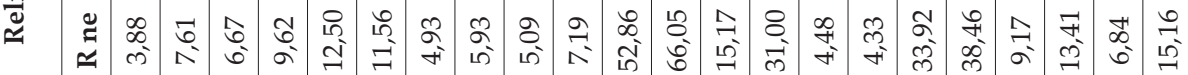

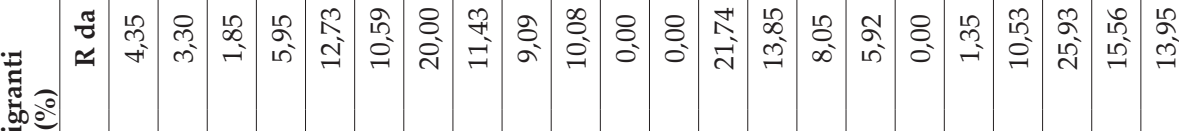

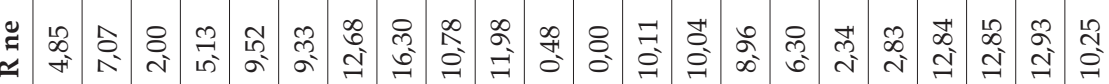

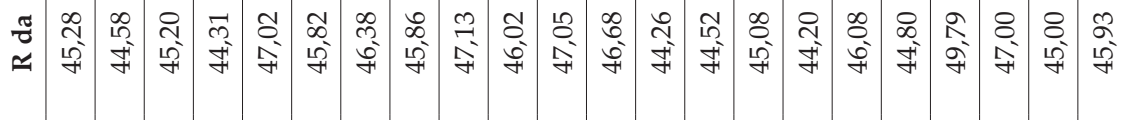
을

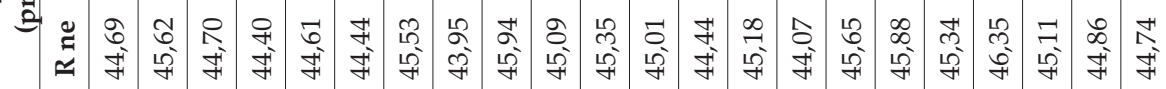

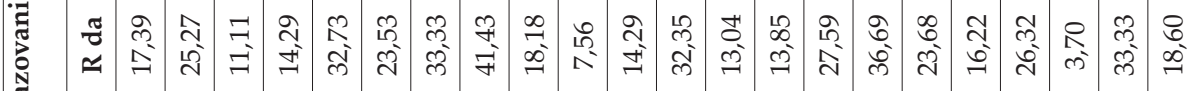
ํㅠㅇ

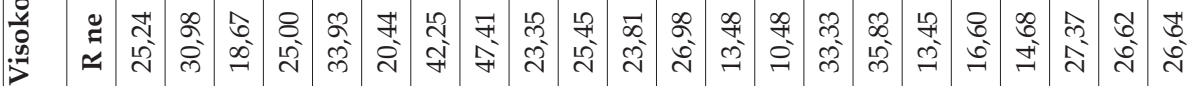

$\approx$

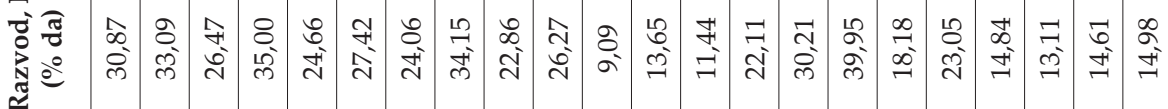

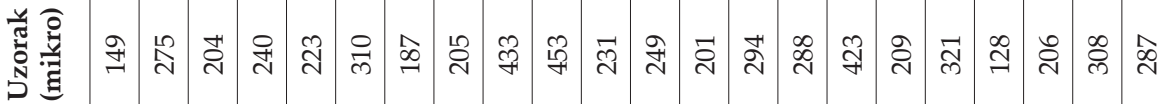

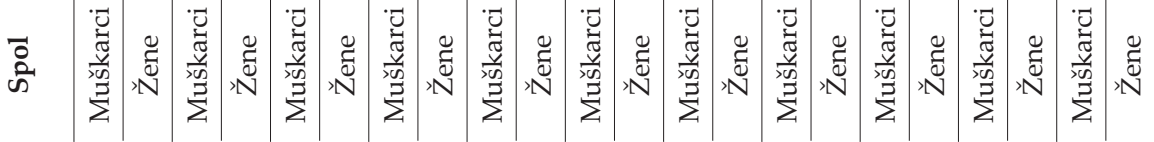

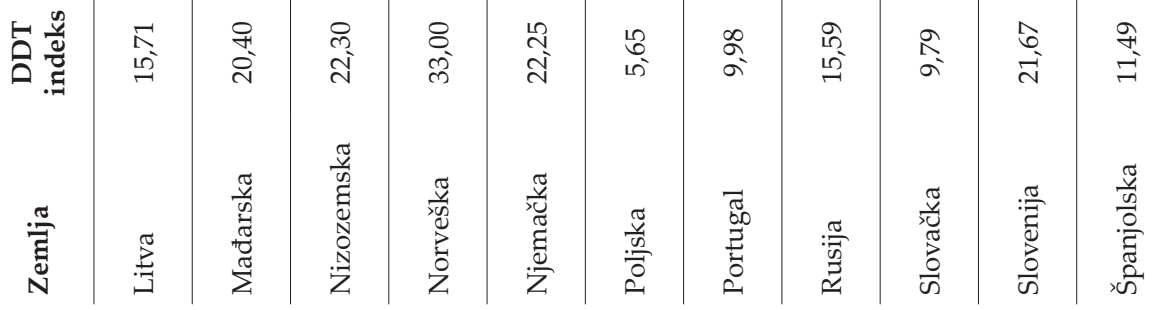




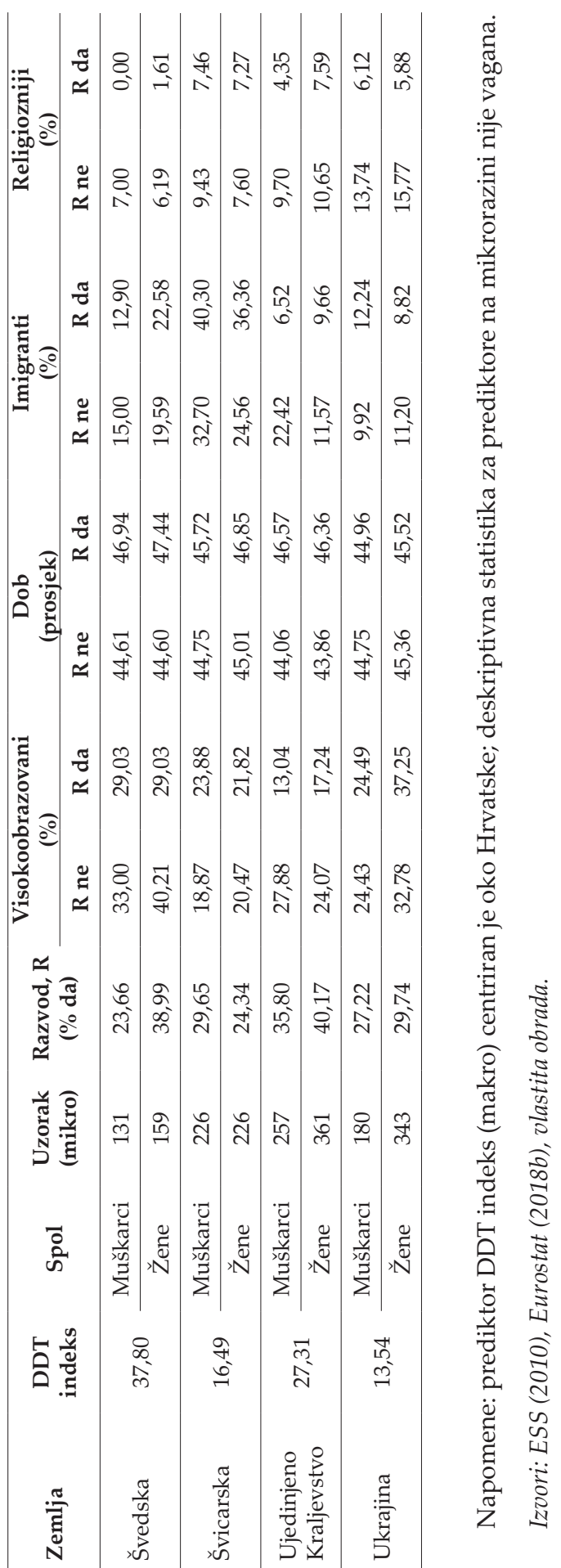


Očekivano, iz tablice 1 uočljivo je da su najveće vrijednosti DDT indeksa zabilježene u skandinavskim zemljama (i Estoniji). Također očekivano, postotni udjeli ikad razvedenih muškaraca i žena jako se razlikuju među zemljama, a Hrvatska je na dnu ljestvice, kao i u slučaju DDT indeksa.

Što se tiče postotnog udjela visokoobrazovanih među (ne)razvedenim muškarcima i ženama, iz tablice 1 vidljive su opet, u skladu s pretpostavkama, velike međunarodne razlike. Te razlike nešto su slabije kod muškaraca nego kod žena, no u većini zemalja u uzorku visokoobrazovanih ima manje među razvedenim nego među nerazvedenim muškarcima (u 18 od 25 zemalja) i ženama (u 15 od 25 zemalja).

Tablica 1 nadalje sugerira da se razvedeni muškarci i žene od nerazvedenih razlikuju i s obzirom na ostale (mikro) prediktore. Razvedeni muškarci u pravilu su stariji od nerazvedenih, dok za žene vrijedi isto u više od $70 \%$ zemalja. Ovdje valja napomenuti da dob može odražavati dva različita učinka: s jedne strane, stariji su ispitanici imali »više vremena « za razvod, no s druge strane, mlađi ispitanici pripadaju mlađim generacijama, koje bi mogle biti sklonije manje tradicionalnim obiteljskim oblicima. Religioznijih u pravilu ima više među nerazvedenim nego među razvedenim muškarcima i ženama, a razlike prema migrantskim obilježjima manje su indikativne.

\subsection{Procjene iz dvorazinske binarne logističke regresije}

Tablica 2 sažima rezultate iz višerazinske analize u ovom radu. Model 1 sadržava samo varijablu o obrazovanju. Procjene sugeriraju da visoko obrazovanje spušta šanse za razvod: među Europljanima za 22,3\% (uz p-vrijednost < 0,01) i među Europljankama za 19,1\% (uz p-vrijednost <0,01). Drugim riječima, šanse za razvod manje su za visokoobrazovane nego za sve ostale muškarce i žene. To odgovara na prvo istraživačko pitanje. Parametar uz konstantu pokazuje da su sveukupne šanse za razvod za muškarce i žene koji nemaju visoko obrazovanje redom 0,277 i 0,342. Model 1 statistički je bolji od nultog modela. Varijanca u šansama za razvod među europskim zemljama blago je porasla kad se u model uvrstila varijabla o obrazovanju, što upućuje na to da u distribuciji visokoobrazovanih muškaraca i žena postoje međunarodne razlike.

U Model 2 uz varijablu o obrazovanju ulaze i ostali prediktori na mikrorazini. Važno je primijetiti da to nije znatnije promijenilo parametar uz varijablu o obrazovanju, iako slabija veza s visokim obrazovanjem u Modelu 2 sugerira da kontrolne varijable "pokrivaju « jedan (manji) dio obrazovnih razlika u šansama za razvod. Veće šanse za razvod pronađene su među sta- 
rijim i manje religioznim muškarcima i ženama i među imigrantima. Model 2 pokazao se statistički boljim od Modela 1.

Tablica 2. Modelske procjene

Table 2. Multilevel logit models

\section{Procijenjeni omjeri šansi za muškarce}

\begin{tabular}{|c|c|c|c|c|c|}
\hline & Model 1 & Model 2 & Model 3 & Model 4 & Model 5 \\
\hline \multicolumn{6}{|l|}{ Visoko obrazovanje } \\
\hline $\mathrm{Ne}$ & ref. & ref. & ref. & ref. & ref. \\
\hline $\mathrm{Da}$ & $0,777^{* * *}$ & $0,804^{* * *}$ & $0,804^{* * *}$ & $0,798^{* * *}$ & 1,138 \\
\hline \multicolumn{6}{|l|}{ Dob } \\
\hline $35-39$ & & $0,558^{* * *}$ & $0,558^{* * *}$ & $0,563^{* * *}$ & $0,563^{* * *}$ \\
\hline $40-44$ & & $0,829 * *$ & $0,829^{* *}$ & 0,832 ** & 0,831 ** \\
\hline $45-49$ & & 0,955 & 0,955 & 0,955 & 0,956 \\
\hline $50-54$ & & ref. & ref. & ref. & ref. \\
\hline \multicolumn{6}{|l|}{ Rođeni u zemlji } \\
\hline $\mathrm{Da}$ & & ref. & ref. & ref. & ref. \\
\hline $\mathrm{Ne}$ & & $1,197^{*}$ & $1,197^{*}$ & $1,193^{*}$ & 1,191 \\
\hline \multicolumn{6}{|l|}{$\begin{array}{l}\text { Vjerski obredi } \\
\text { najmanje tjedno }\end{array}$} \\
\hline $\mathrm{Ne}$ & & ref. & ref. & ref. & ref. \\
\hline $\mathrm{Da}$ & & $0,448^{* * *}$ & $0,448^{* * *}$ & $0,457^{* * *}$ & $0,458^{* * *}$ \\
\hline DDT indeks & & & & $1,033^{* * *}$ & $1,037^{* * *}$ \\
\hline $\begin{array}{l}\text { DDT indeks } x \text { x } \\
\text { visoko obrazovanje }\end{array}$ & & & & & $0,983^{* *}$ \\
\hline Konstanta & $0,277^{* * *}$ & $0,341 * * *$ & $0,341^{* * *}$ & $0,190^{* * *}$ & $0,177^{* * *}$ \\
\hline $\begin{array}{l}\text { Varijanca među } \\
\text { zemljama (SE) }\end{array}$ & $\begin{array}{c}0,254 \\
(0,084)\end{array}$ & $\begin{array}{c}0,209 \\
(0,072)\end{array}$ & $\begin{array}{c}0,209 \\
(0,072)\end{array}$ & $\begin{array}{c}0,100 \\
(0,039)\end{array}$ & $\begin{array}{c}0,096 \\
(0,037)\end{array}$ \\
\hline $\begin{array}{l}\text { Varijanca za visoko } \\
\text { obrazovanje (SE) }\end{array}$ & l & l & $\begin{array}{c}0,001 \\
(0,049)\end{array}$ & l & l \\
\hline $\begin{array}{l}\text { LR test: koji je model } \\
\text { bolji }\end{array}$ & 1 od $0 * * *$ & 2 od $1^{* * *}$ & 3 od 2 & 4 od $2^{* * *}$ & 5 od $4^{* *}$ \\
\hline
\end{tabular}




\begin{tabular}{|c|c|c|c|c|c|}
\hline \multicolumn{6}{|c|}{ Procijenjeni omjeri šansi za žene } \\
\hline & Model 1 & Model 2 & Model 3 & Model 4 & Model 5 \\
\hline \multicolumn{6}{|l|}{ Visoko obrazovanje } \\
\hline $\mathrm{Ne}$ & ref. & ref. & ref. & ref. & ref. \\
\hline $\mathrm{Da}$ & $0,809^{* * *}$ & $0,817^{* * *}$ & $0,810^{* *}$ & $0,804^{* *}$ & 1,205 \\
\hline \multicolumn{6}{|l|}{ Dob } \\
\hline $35-39$ & & $0,716^{* * *}$ & $0,716^{* * *}$ & $0,718^{* * *}$ & $0,716^{* * *}$ \\
\hline $40-44$ & & 0,955 & 0,960 & 0,960 & 0,957 \\
\hline $45-49$ & & 1,107 & 1,108 & 1,106 & 1,105 \\
\hline $50-54$ & & ref. & ref. & ref. & ref. \\
\hline \multicolumn{6}{|l|}{ Rođeni u zemlji } \\
\hline $\mathrm{Da}$ & & ref. & ref. & ref. & ref. \\
\hline $\mathrm{Ne}$ & & $1,204^{* *}$ & $1,202^{* *}$ & $1,191^{*}$ & $1,193^{*}$ \\
\hline \multicolumn{6}{|l|}{$\begin{array}{l}\text { Vjerski obredi } \\
\text { najmanje tjedno }\end{array}$} \\
\hline $\mathrm{Ne}$ & & ref. & ref. & ref. & ref. \\
\hline $\mathrm{Da}$ & & $0,569^{* * *}$ & $0,572^{* * *}$ & $0,584^{* * *}$ & $0,587^{* * *}$ \\
\hline DDT indeks & & & & $1,034^{* * *}$ & $1,037^{* * *}$ \\
\hline $\begin{array}{l}\text { DDT indeks } x \text { x } \\
\text { visoko obrazovanje }\end{array}$ & & & & & $0,979^{* *}$ \\
\hline Konstanta & $0,342^{* * *}$ & $0,379^{* * *}$ & $0,378^{* * *}$ & $0,209^{* * *}$ & $0,199 * * *$ \\
\hline $\begin{array}{l}\text { Varijanca među } \\
\text { zemljama (SE) }\end{array}$ & $\begin{array}{c}0,267 \\
(0,084)\end{array}$ & $\begin{array}{c}0,226 \\
(0,073)\end{array}$ & $\begin{array}{c}0,231 \\
(0,075)\end{array}$ & $\begin{array}{c}0,118 \\
(0,041)\end{array}$ & $\begin{array}{c}0,118 \\
(0,041)\end{array}$ \\
\hline $\begin{array}{l}\text { Varijanca za visoko } \\
\text { obrazovanje (SE) }\end{array}$ & l & / & $\begin{array}{c}0,100 \\
(0,064)\end{array}$ & $\begin{array}{c}0,119 \\
(0,070)\end{array}$ & $\begin{array}{c}0,071 \\
(0,054) \\
\end{array}$ \\
\hline $\begin{array}{l}\text { LR test: koji je model } \\
\text { bolji }\end{array}$ & 1 od $0^{* * *}$ & 2 od $1^{* * *}$ & 3 od $2^{* * *}$ & 4 od $3^{* * *}$ & 5 od $4^{* *}$ \\
\hline
\end{tabular}

Napomene: ${ }^{* * *} \mathrm{p}<0,01 ;{ }^{* *} \mathrm{p}<0,05 ;{ }^{*} \mathrm{p}<0,10$; ref. $=$ referentna kategorija; SE $=$ standardna pogreška; model $0=$ prazan (nulti) model.

Model 3 dopušta da koeficijent uz varijablu o obrazovanju varira među zemljama. Statistički je bolji od Modela 2 za žene, ali ne i za muškarce, pa se može reći da je odgovor na drugo istraživačko pitanje »polovično« potvrdan. To odgovara dosadašnjim empirijskim nalazima koji u različitim europskim zemljama dokumentiraju uglavnom negativnu vezu između obrazovanja i razvoda kod muškaraca.

U Model 4 uvrštena je varijabla DDT indeks. Budući da je ta varijabla centrirana, konstanta u Modelu 4 pokazuje kolike su šanse za razvod u Hrvatskoj uz referentne vrijednosti za sve ostale (mikro) prediktore. Jedinično povećanje u DDT indeksu povećava šanse za razvod: među muškarcima za 
3,3\% (uz p-vrijednost $<0,01$ ) i među ženama za 3,4\% (uz p-vrijednost $<0,01$ ). Dakle Model 4 dokazuje očekivano; što je druga demografska tranzicija u nekoj zemlji raširenija, to su i šanse za razvod na mikrorazini veće. Dodatno, varijanca $\mathrm{u}$ šansama za razvod među europskim zemljama u Modelu 4 znatno je manja nego u prethodnim specifikacijama. To znači da DDT indeks objašnjava dobar dio međunarodnih razlika u šansama za razvod. U Modelu 4 udio ukupne varijance koji otpada na razlike među zemljama spustio se s početnih 7,0\% iz nultog modela na manje od 3,0\% za muškarce i s početnih $7,3 \%$ iz nultog modela na manje od $3,5 \%$ za žene. Formalni testovi potvrđuju da je Model 4 statistički bolji od Modela 2 za muškarce i od Modela 3 za žene.

U Modelu 5 procijenjena je interakcija između DDT indeksa i visokog obrazovanja. Iako za muškarce u Modelu 3 nisu pronađene naznake da obrazovni gradijent $u$ razvodu varira među europskim zemljama, to ne znači da se ne može procijeniti mikro-makro interakcija. Štoviše, pojedini autori (Snijders i Bosker, 1999: 75, 96) ističu da je signifikantna mikro-makro interakcija pouzdanija za pronalaženje razlika u vezi na mikrorazini među entitetima na makrorazini. U Modelu 5 i među muškarcima i među ženama pronađena je signifikantna interakcija između DDT indeksa i visokog obrazovanja (uz p-vrijednost $<0,05$ i za muškarce i za žene). To znači da obrazovni gradijent $u$ razvodu ovisi o nacionalnim demografskim značajkama. Parametar uz mikro-makro interakciju odgovara na treće istraživačko pitanje i otkriva da su šanse za razvod među visokoobrazovanim muškarcima i ženama manje u zemljama gdje je druga demografska tranzicija raširenija, što je u skladu s teorijskim pretpostavkama.

U Modelu 5 parametar uz varijablu o obrazovanju odnosi se na Hrvatsku, tj. na zemlju u kojoj DDT indeks ima vrijednost 0 . Zanimljivo je primijetiti da su u Hrvatskoj, prema procjenama u Modelu 5, šanse za razvod veće (premda ne signifikantno) za visokoobrazovane nego za sve ostale muškarce i žene. To sugerira, također u skladu s teorijskim pretpostavkama, da veza između visokog obrazovanja i razvoda prelazi iz pozitivne $u$ negativnu u zemljama gdje je druga demografska tranzicija izraženija.

Slika 1 za muškarce i slika 2 za žene prikazuju kako se veza između visokog obrazovanja i razvoda mijenja ovisno o DDT indeksu. Na temelju Modela 5 procijenjene su vjerojatnosti za razvod posebno za dvije obrazovne kategorije (za muškarce i žene s visokim obrazovanjem i za muškarce i žene s nižim od visokog obrazovanja) pri različitim vrijednostima DDT indeksa. Proizašle procjene upućuju na slične obrasce među spolovima. 
Slika 1. Mikro-makro interakcija: procjene za muškarce

Figure 1. Cross-level interaction effects: estimates for males

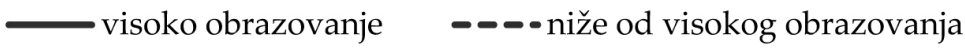

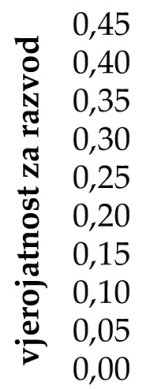

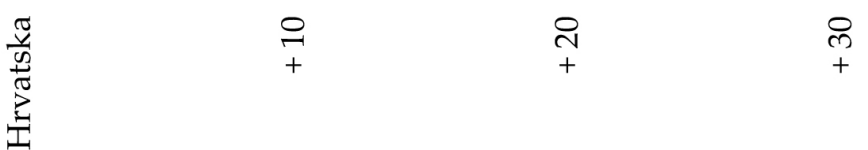

DDT indeks

Slika 2: Mikro-makro interakcija: procjene za žene

Figure 2. Cross-level interaction effects: estimates for females

— visoko obrazovanje _----niže od visokog obrazovanja

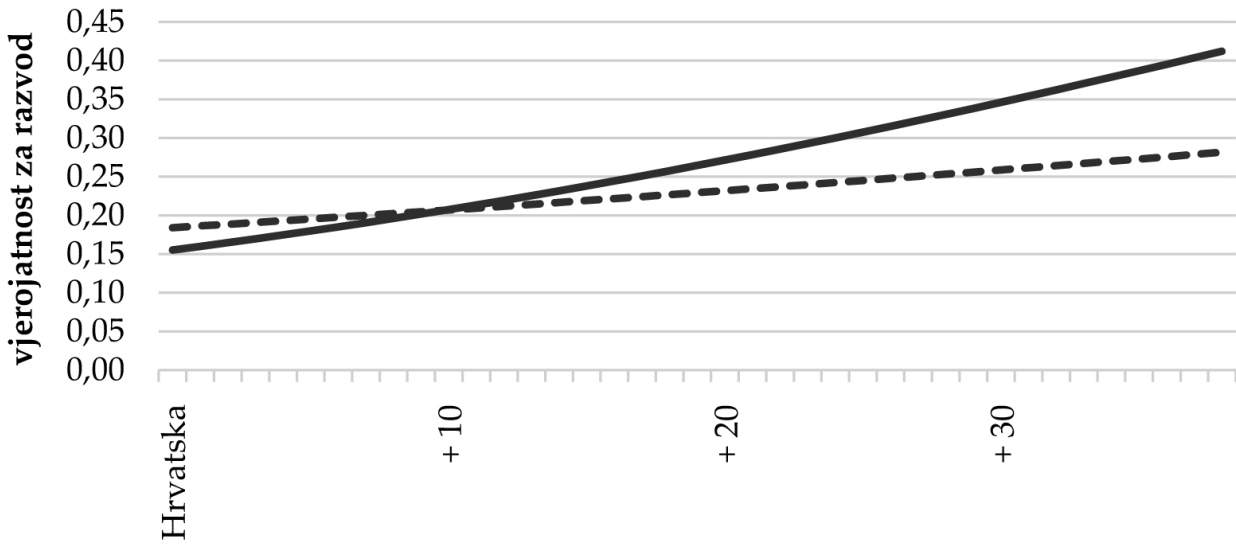

\section{DDT indeks}

U Hrvatskoj, gdje DDT indeks ima najmanju vrijednost, procijenjena vjerojatnost za razvod veća je (premda ne signifikantno) među visokoobrazo- 
vanim muškarcima (slika 1) i ženama (slika 2). Vjerojatnost za razvod kod obje se obrazovne kategorije povećava s DDT indeksom. No taj je porast sporiji za one visokoobrazovane, koji pri najvećim vrijednostima DDT indeksa imaju signifikantno nižu vjerojatnost za razvod.

\section{RASPRAVA I ZAKLJUČAK}

Različite teorije donose različite pretpostavke o obrazovnom gradijentu u razvodu. Ovaj rad istražio je vezu između visokog obrazovanja i razvoda u međunarodnoj perspektivi. Rezultati provedenog istraživanja pokazali su da visoko obrazovanje spušta šanse za razvod među Europljanima i Europljankama u jednoj dobnoj kohorti. Negativna se veza zadržala i nakon što su se u obzir uzele kontrolne varijable. To ide u prilog teorijama koje sugeriraju da visoko obrazovanje partnerima nudi socioekonomske prednosti koje promiču bračnu stabilnost.

U radu se u sljedećem koraku ispitalo varira li obrazovni gradijent u razvodu među europskim zemljama, a zatim i ovisi li i kako o kontekstualnim uvjetima. U višerazinskim regresijskim modelima pronađene su međunarodne razlike u vezi između visokog obrazovanja i razvoda za žene, ali ne i za muškarce. No procijenjene mikro-makro interakcije potvrdile su da veza između visokog obrazovanja i razvoda - za oba spola - ovisi o nacionalnim demografskim značajkama. U europskim zemljama gdje su manje tradicionalni obiteljski oblici najčešći visoko obrazovanje spušta šanse za razvod. S druge strane, u zemljama poput Hrvatske, gdje je prema prikupljenim pokazateljima druga demografska tranzicija još uvijek relativno slaba, može se očekivati manje negativna ili pozitivna veza s visokim obrazovanjem. Drugim riječima, ovi rezultati odgovaraju hipotezi da modernizacija i promjene $u$ vrijednosnom sustavu i društvenoj organizaciji koje prate drugu demografsku tranziciju smanjuju zapreke razvodu, što vezu s visokim obrazovanjem čini sve manje pozitivnom odnosno sve više negativnom. Takav zaključak slaže se s argumentima i rezultatima iz postojeće teorijske (Goode, 1962, 1993; Lesthaeghe i Surkyn, 1988; Blossfeld i sur., 1995) i empirijske (Härkönen i Dronkers, 2006; Matysiak, Styrc i Vignoli, 2014) literature.

Budući da je razvod dvočlan događaj, jedno je ograničenje ovog istraživanja to što su (mikro) analitičke jedinice muškarci i žene, a ne bračni parovi. Teorija predviđa da šanse za razvod ovise o muževim i ženinim zajedničkim socioekonomskim atributima i u empirijskim je analizama poželjno to uvažiti (Jalovaara, 2003; Lyngstad, 2004). Kao i u nekim drugim istraživanjima (Härkönen i Dronkers, 2006; Salvini i Vignoli, 2011), u ovom 
istraživanju to otežavaju nedovoljno detaljni podaci. Zato se u višerazinskoj analizi u ovom radu nije ispitalo ovisi li i kako o kontekstualnim uvjetima i veza između obrazovne homo/heterogamije i razvoda, što je zanimljiv zadatak za buduća istraživanja.

Još je jedno ograničenje ovog istraživanja to što zavisna varijabla razvod ne razlikuje od prekida zakonski priznate izvanbračne zajednice. Na primjer iz dostupnih podataka nije se moglo provjeriti mijenjaju li se šanse razvod na isti način s kontekstualnim uvjetima kao i šanse za prekid zakonski priznate izvanbračne zajednice. Također se nije moglo provjeriti kako bi (ako bi uopće) izuzimanje zakonski priznatih izvanbračnih zajednica iz višerazinske analize promijenilo rezultate. Iako se u literaturi vodi debata o sličnostima između braka i izvanbračne kohabitacije i mnogi bi čimbenici mogli imati sličan utjecaj na njihovu stabilnost, među ovim obiteljskim oblicima i dalje postoje razlike (Härkönen, 2014).

Na kraju, iako se ovo istraživanje zasniva na presječnim podacima, rezultati su dosljedni promjenama koje se tijekom vremena bilježe u vezi između obrazovanja i razvoda (Härkönen i Dronkers, 2006; Dronkers, 2015). Ako se $\mathrm{s}$ difuzijom inovacija u obiteljskom ponašanju u sklopu druge demografske tranzicije može očekivati pomak prema sve više negativnoj vezi između obrazovanja i razvoda, to bi one u nižim društvenim slojevima moglo dovesti u (još) nepovoljniji položaj (McLanahan, 2004; McLanahan i Percheski, 2008; McLanahan i Jacobsen, 2015). Ova hipoteza traži empirijsku provjeru, a dosadašnja istraživanja sugeriraju da bi rezultati i u ovom slučaju mogli ovisiti o kontekstualnim uvjetima (Bernardi i Boertien, 2017).

\section{LITERATURA}

Amato, P. R. (1996). Explaining the Intergenerational Transmission of Divorce, Journal of Marriage and Family, 58 (3): 628-640, doi: https://doi.org/10.2307/353723

Amato, P. R. (2000). The Consequences of Divorce for Adults and Children, Journal of Marriage and Family, 62 (4): 1269-1287, doi: https://doi.org/10.1111/j.17413737.2000.01269.x

Amato, P. R. (2014). The Consequences of Divorce for Adults and Children: An Update, Društvena istraživanja, 23 (1): 5-24, doi: https://doi.org/10.5559/di.23.1.01

Becker, G. S. (1974). A Theory of Marriage, u: T. W. Schultz (ur.). Economics of the Family: Marriage, Children, and Human Capital. Chicago: University of Chicago Press, 299344, https://www.nber.org/chapters/c2970.pdf (5.12.2018.).

Becker, G. S. (1993). A Treatise on the Family (Enlarged edition). Cambridge, MA: Harvard University Press. 
Becker, G. S., Landes, E. M. i Michael, R. T. (1977). An Economic Analysis of Marital Instability, Journal of Political Economy, 85 (6): 1141-1187, doi: https://doi. org/10.1086/260631

Bernardi, F. i Boertien, D. (2017). Non-intact families and diverging educational destinies: A decomposition analysis for Germany, Italy, the United Kingdom and the United States, Social Science Research, 63: 181-191, doi: https://doi.org/10.1016/j. ssresearch.2016.09.004

Blossfeld, G. J. (2014). Educational Assortative Mating and Divorce: A Longitudinal Analysis of the Influences of Education on the Divorce Rate for Different Educational Matches. Population Association of America - Annual Meeting, Boston, MA, May 1-3, 2014, http://paa2014.princeton.edu/papers/141481 (6.12.2018.).

Blossfeld, H.-P., De Rose, A., Hoem, J. M. i Rohwer, G. (1995). Education, Modernization, and the Risk of Marriage Disruption in Sweden, West Germany, and Italy, u: K. O. Mason i A.-M. Jensen (ur.). Gender and Family Change in Industrialized Countries. Oxford: Clarendon Press, 200-222.

Dronkers, J. (2015). The Changing Impact of Education on Divorce and Break-up Risk [Blog post], Charlottesville, VA: IFS, https://ifstudies.org/blog/the-changing-impact-ofeducation-on-divorce-and-break-up-risk (6.12.2018.).

ESS (2010). ESS Round 5: European Social Survey Round 5 Data. Data file edition 3.4. NSD - Norwegian Centre for Research Data, Norway - Data Archive and distributor of ESS data for ESS ERIC.

ESS (2014). Weighing European Social Survey Data. European Social Survey. https:// www.europeansocialsurvey.org/docs/methodology/ESS_weighting_data_1.pdf (5.12.2018.).

ESS (2018). ESS Round 5: European Social Survey: ESS-5 2010 Documentation Report. Edition 4.2. Bergen, European Social Survey Data Archive, NSD - Norwegian Centre for Research Data for ESS ERIC.

Eurostat (2018a). Marriage and divorce statistics. https://ec.europa.eu/eurostat/statisticsexplained/index.php/Marriage_and_divorce_statistics (5.12.2018.).

Eurostat (2018b). Fertility statistics. https://ec.europa.eu/eurostat/statistics-explained/ index.php/Fertility_statistics (5.12.2018.).

Goode, W. J. (1951). Economic Factors and Marital Stability, American Sociological Review, 16 (6): 802-812, doi: https://doi.org/10.2307/2087507

Goode, W. J. (1962). Marital satisfaction and instability: a cross-cultural analysis of divorce rates, International Social Science Journal, 14 (3): 507-526, https://unesdoc. unesco.org/ark:/48223/pf0000017391 (5.12.2018.).

Goode, W. J. (1993). World Changes in Divorce Patterns. New Haven, CT: Yale University Press.

Härkönen, J. (2014). Divorce: Trends, Patterns, Causes, and Consequences, u: J. Treas, J. Scott i M. Richards (ur.). The Wiley Blackwell Companion to the Sociology of Families (First edition). Chichester: John Wiley and Sons, 303-322, doi: https://doi. org/10.1002/9781118374085

Härkönen, J. i Dronkers, J. (2006). Stability and Change in the Educational Gradient of Divorce. A Comparison of Seventeen Countries, European Sociological Review, 22 (5): 501-517, doi: https://doi.org/10.1093/esr/jcl011 
Hoem, J. M. (1997). Educational Gradients in Divorce Risks in Sweden in Recent Decades, Population Studies, 51 (1): 19-27, doi: https://doi.org/10.1080/0032472031000149696

Jalovaara, M. (2003). The Joint Effects of Marriage Partners' Socioeconomic Positions on the Risk of Divorce, Demography, 40 (1): 67-81, doi: https://doi.org/10.1353/ dem.2003.0004

Kalmijn, M. (2013). The Educational Gradient in Marriage: A Comparison of 25 European Countries. Demography, 50 (4): 1499-1520, doi: https://doi.org/10.1007/s13524-0130229-x

Lesthaeghe, R. (1995). The Second Demographic Transition in Western Countries: An Interpretation, u: K. O. Mason i A.-M. Jensen (ur.). Gender and Family Change in Industrialized Countries. Oxford: Clarendon Press, 17-62.

Lesthaeghe, R. i Surkyn, J. (1988). Cultural Dynamics and Economic Theories of Fertility Change, Population and Development Review, 14 (1): 1-45, doi: https://doi. org/10.2307/1972499

Levinger, G. (1976). A Social Psychological Perspective on Marital Dissolution, Journal of Social Issues, 32 (1): 21-47, doi: https://doi.org/10.1111/j.1540-4560.1976.tb02478.x

Lyngstad, T. H. (2004). The Impact of Parents' and Spouses' Education on Divorce Rates in Norway, Demographic Research, 10 (5): 121-142, doi: https://doi.org/10.4054/ DemRes.2004.10.5

Matysiak, A., Styrc, M. i Vignoli, D. (2014). The educational gradient in marital disruption: A meta-analysis of European research findings, Population Studies, 68 (2): 197-215, doi: https://doi.org/10.1080/00324728.2013.856459

McLanahan, S. (2004). Diverging Destinies: How Children Are Faring under the Second Demographic Transition, Demography, 41 (4): 607-627, doi: https://doi.org/10.1353/ dem.2004.0033

McLanahan, S. i Jacobsen, W. (2015). Diverging Destinies Revisited, u: P. R. Amato, A. Booth, S. M. McHale i J. Van Hook (ur.). Families in an Era of Increasing Inequality, Cham: Springer International Publishing, 3-23, doi: https://doi.org/10.1007/978-3319-08308-7_3

McLanahan, S. i Percheski, C. (2008). Family Structure and the Reproduction of Inequalities. Annual Review of Sociology, 34: 257-276 doi: https://doi.org/10.1146/ annurev.soc.34.040507.134549

Oppenheimer, V. K. (1997). Women's Employment and the Gain to Marriage: The Specialization and Trading Model, Annual Review of Sociology, 23: 431-453, doi: https://doi.org/10.1146/annurev.soc.23.1.431

Salvini, S. i Vignoli, D. (2011). Things change: Women's and men's marital disruption dynamics in Italy during a time of social transformations, 1970 - 2003, Demographic Research, 24 (5): 145-174, doi: https://doi.org/10.4054/DemRes.2011.24.5

Snijders, T. A. B. i Bosker, R. J. (1999). Multilevel Analysis: An Introduction to Basic and Advanced Multilevel Modeling. London: Sage Publications.

van de Kaa, D. J. (1987). Europe's Second Demographic Transition, Population Bulletin, 42 (1): 1-59. 


\title{
High Education and Divorce in a Cross- national Comparison: How Do Country-specific Population Characteristics Influence a Micro-level Relationship?
}

\section{Petra Međimurec}

\begin{abstract}
SUMMARY
Europe saw a substantial rise in divorce over the last decades (Eurostat, 2018a). However, this general increase was very uneven: divorce occurs more frequently not only in some countries, but also in some socioeconomic categories. This study examines the relationship between high education and divorce from a multinational perspective. More specifically, the following research questions are addressed: a) How does high education affect the odds of divorce in Europe?; b) Does the relationship between high education and divorce vary across countries?; c) Do nation-specific demographic factors mediate this relationship, and how does Croatia compare to other European countries?
\end{abstract}

Different theories provide different arguments about how education relates to marital (in)stability. For example, some suggest that better-educated spouses have more liberal attitudes that make it easier to opt for a divorce (Levinger, 1976). However, most economic and psychosocial theories see high education as a factor that tends to stabilize marriages among men (Jalovaara, 2003). Becker's family model (Becker, 1974, 1993; Becker, Landes and Michael, 1977) views the mutual dependence of spouses as a key source of gains to marriage. Because men have typically held a comparative advantage in the labour market and women in domestic work, Becker argues that gains to marriage are maximised when men who have a high economic potential partner with women having low economic potential. For men, high education raises the efficiency of role specialisation, thus reducing the odds of divorce. In contrast, for women, high education decreases the benefits of a traditional gendered division of labour, thus elevating the odds of divorce. A different line of reasoning (Oppenheimer, 1997) asserts that the wife's high education lessens marital strain (and therefore also lessens the odds of divorce) as it improves the family's socioeconomic status and living standard. Moreover, education can boost couples' gains to marriage by bettering communication skills and the ability to solve conflicts (Amato, 1996; Blossfeld, 2014).

Empirical studies report mixed evidence too: divorce appears to be more common among the highly-educated in some countries and in some cohorts, but less common among the highly-educated in other countries and in other cohorts (Härkönen and Dronkers, 2006; Dronkers, 2015). Well-known theories of family change discuss possible reasons.

According to Goode (1962, 1993), one can anticipate a negative or a less positive relationship between high education and divorce in the countries with relatively little barriers to divorce. If barriers to divorce are high, divorce is more affordable to the upper strata. As barriers to divorce decline, lower strata - who generally experience more marital strain (Goode, 1951, 1962) - in turn become increasingly likely to 
divorce. Other accounts lead to similar predictions. The second demographic transition view (van de Kaa, 1987; Lesthaeghe, 1995) posits that new and less traditional family practices are first adopted by highly-educated innovators, before spreading among the lower strata through imitation (Lesthaeghe and Surkyn, 1988). In this vein, Blossfeld et al. (1995) argue that high education increases the odds of divorce in countries where divorce is still rare, because in such countries divorce violates the established social norms more severely. This association weakens in countries where divorce is more common, and conventions surrounding family life are less strict. In Goode's words, this makes barriers to divorce lower, and thus reversing the educational gradient.

To test these explanations, this study delivers a comparative multilevel analysis of the educational gradient in divorce across 25 European countries. Individual-level data are drawn from the European Social Survey Round 5 integrated database (ESS, 2010). The sample includes ever married respondents, who were 35 to 54 years old at the time of the interview. Respondents with a missing value on the dependent variable or any of the predictor variables are excluded (around 1,6\%) from the sample. The sample also excludes Israel (the focus is on European countries), and Finland (because of a mistake in the question concerning marital status).

The outcome variable are the odds of being divorced. High education is the main micro-level predictor variable. It was coded as a dummy variable, indicating whether a man or a woman has successfully completed tertiary education (ISCED 2011 level 6 or higher). The following control variables are used: age, immigrant status, and religiosity.

Three measures are used to depict the country-specific demographic context: the percentage share of ever divorced men and women, the percentage share of men and women who have ever cohabitated (these two items are derived from the full European Social Survey Round 5 sample), and the percentage share of extramarital births (Eurostat, 2018b). The three measures form a good scale at the macro-level (Cronbach's alpha $>0,80$ ), and they are combined into a single variable to proxy the family life environment, i.e. the innovativeness of divorce, its costs, and the rigidity of social norms.

Multilevel modelling for binary response variables is used since the outcome variable is dichotomous. The models are estimated separately for men and women. Five models, starting with the unconditional (null) model to the model with cross-level interactions, are fitted.

The first result reveals that high education lowers the odds of divorce among men and women in Europe. This is in line with the theories asserting that high education improves the economic, cultural, and social resources that benefit marital stability.

The second result pertains to cross-national differences in the educational effect. For men, no random slope in high education is found. However, for women, the educational gradient was found to vary significantly across European countries.

In the next step, the macro-level variable is entered into the models. The logit coefficient estimates confirm that the odds of divorce are higher in countries where less conventional family behaviours are more prevalent. With regard to cross-level interactions, the logit coefficient estimates are found to be significant for both men and women, indicating that the effect of high education on the odds of divorce differs across European countries. This result outweighs the non-significant random slope 
in high education among men (Snijders and Bosker, 1999: 75, 96). In the countries where barriers to divorce are lower, and family practices are less conventional, high education decreases the odds of divorce. In Croatia, where barriers to divorce are still comparatively high, the social context is found to stimulate the relationship between education and divorce to be less negative (more positive).

My findings are in line with the conclusions from prior studies (Härkönen and Dronkers, 2006; Matysiak, Styrc and Vignoli, 2014; Dronkers, 2015). Although the main goal of the current study was to gain a better understanding of cross-country differences, the findings are consistent with trends reported over time in the relationship between education and divorce. Innovation in family practices associated with the second demographic transition is once again confirmed to produce an increasingly negative educational gradient of divorce, and some authors see this as a mechanism in the reproduction of social inequalities (McLanahan, 2004; McLanahan and Percheski, 2008; McLanahan and Jacobsen, 2015). Such a hypothesis calls for more empirical research, with available evidence suggesting that contextual variables might play an important role in this instance too (Bernardi and Boertien, 2017).

KEY WORDS: divorce, education, cross-national comparison, Europe, multi-level analysis 